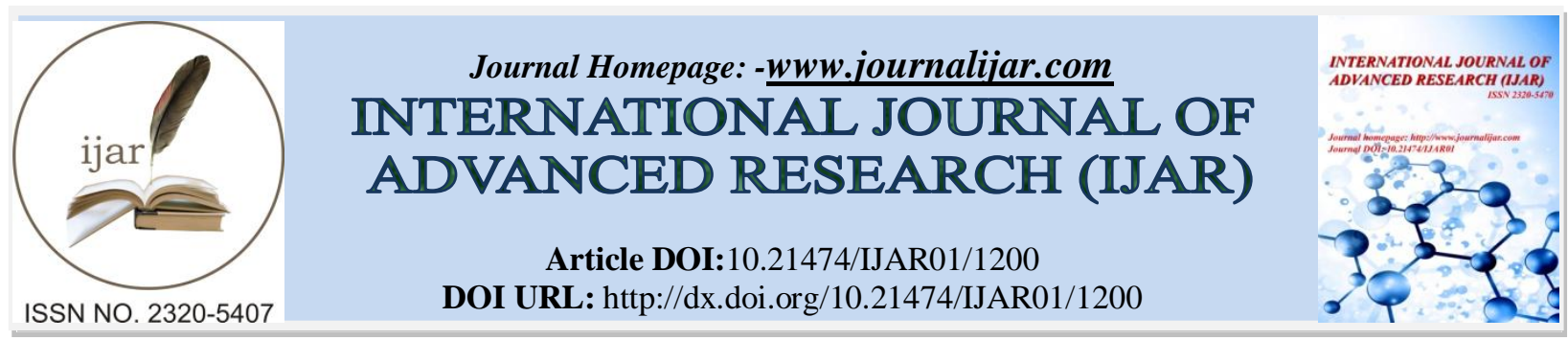

RESEARCH ARTICLE

\title{
THE EFFECTIVENESS OF ASSET AND LIABILITY MANAGEMENT AS A PANACEA TO BANKS PROFITABILITY IN INDIA.
}

\section{GODFRED KESSE OPPONG.}

Joseph School of Business Studies, Sam Higginbottom Institute of Agriculture, Technology \& Sciences, 211007Allahabad, Uttar Pradesh-India.

\section{Manuscript Info}

Manuscript History

Received: 13 June 2016

Final Accepted: 19 July 2016

Published: August 2016

Key words:-

Asset Liability Management (ALM),

Risk, Profitability, Asset Liability

Committee (ALCO).

\begin{abstract}
Indian Banking Industry has recently gone through diverse phases in terms development in history right from the onset of liberalization. This has exposed the Industry to uncertainty and to global competition making it imperative to have proper asset liability management system in place. This paper assessed the effectiveness of asset and liability management as a panacea to Banks profitability in India. The objectives of the study were to identity the risk factors associated with asset liability management amongst the selected Banks and to assess the various strategies for managing the interest rate risks of assets and liabilities. The research was carried out on four selected Banks in Lucknow, India, with emphasis on two National Banks and two Private Banks. These were the State Bank of India, Bank of Baroda, Axis Bank and HDFC Bank. The State Head Offices of the selected Banks with 60 respondents were selected as sample size via multi stage sampling technique. Questionnaires were designed consisting of open and closeended questions and data were taken from both primary and secondary sources. Findings indicated that, the Banks' Asset Liability Management involved the effective management of all the risk factors where strategies are also mounted by these Banks in controlling them. It was also recommended that Asset Liability Management is one of the vital tools for risk management in Banks, so Banks have to take great care for that. All Banks have to work properly with regard to the Asset Liability Management to increase their performance.
\end{abstract}

Copy Right, IJAR, 2016, All rights reserved.

\section{Introduction:-}

Indian Banking exordium has been very vigorous over the years. The main drivers of change in the Industry have been regulatory changes, customer relations, technology, service proliferation and competition. With the dynamism in the Indian Banking Industry and increased competition, the need for credit management has even become more intense. The Banking Industry is one of the basic instruments of economic growth. It must be on a sound footing as it constitutes an important link in various socio-economic activities. A strong Banking Sector is important for flourishing the economy. The failure of the Banking Sector in any Country may have an adverse impact on other Sectors.

Banks' role in the economy of any country is very significant. They play intermediation function by making the 
funds flow from surplus into deficits units and in that, availing credit to borrowers is one means by which Banks contribute to the growth of economies. They provide financial services to meet such needs of their clients and prospective ones. These services include; acting as agents on financial markets, transferring of funds (both locally and internationally), granting of loans and overdrafts etc. And these activities are the backbone for economic growth and development of every country (Madura, 2005).

Asset Liability Management is critical for sound management of the finances of any organization that invest to meet its future cash flow needs and capital requirements. Efforts are required to monitor and co-ordinate the activities of Asset Liability Management. Bank's Asset Liability Management (ALM) may be defined as the simultaneous planning of all asset and liability positions on the Bank's balance sheet under consideration of the different Bank management objectives and legal, managerial and market constraints, for the purpose of enhancing the value of the Bank, providing liquidity, and mitigating interest rate risk (Gup and Brooks, 1993).

\section{Objectives:-}

1. To identity the risk factors associated with asset liability management amongst the selected Banks.

2. To assess the various strategies for managing the interest rate risks of assets and liabilities.

\section{Research Problem:-}

The transformation of the Indian financial markets over the past few years, the growing integration of domestic markets with external markets, and the risks associated with Banks operations have become complex and large. The requirement of strategic management in dealing with such complexities is on rise.

However, in the 1970's, policies alone have been found to be ineffective because Banks accustomed to thinking in terms of Accrual Accounting were slow to recognize the emerging risk. Due to this, Banks felt the need for identifying and controlling those risk which could result in serious losses and asset quality became the main focus Banks. Banks realised the need to control and manage both asset and liability with equal care for identifying and controlling these risks, hence, Asset Liability Management became the focus of Banks as a medium of strategic planning and risk management technique.

In this direction, the present paper is undertaken to study the effectiveness of Asset Liability Management as a substitute for Accrual Accounting in the Indian Banking Industrial Sector and the various contributions Asset Liability Management has offered to the success of the selected Banks in India.

\section{Literature review:-}

Literature review congruent to this topic under study is imperative since it serves as a fundamental preparation for this research therefore, emphasis would be played and levied on reviews related to this study. The focus of this chapter is to give theoretical and conceptual foundation of the study. This chapter then presents the literature review focusing on the empirical evidence on determinants of asset liability classifications, asset liability management in general, the risk associated factors, and the various techniques.

\section{Risk Factors Associated with Asset Liability Management:-}

ALM involves assessment of various types of risks and altering the asset- liability portfolio in a dynamic way in order to manage risk.

\section{Interest Rate Risk:-}

Interest risk is the change in prices of bonds that could occur as a result of change in interest rates. It also considers change in impact on interest income due to changes in the rate of interest. In other words, price as well as reinvestment risks require focus. In so far as the terms for which interest rates were fixed on deposits differed from those for which they fixed on assets, banks incurred interest rate risk i.e., they stood to make gains or losses with every change in the level of interest rates.

\section{Liquidity Risk:-}

Liquidity risk is the risk that cash inflow may not be sufficient to cover liabilities or maturing debt obligations. According to Rosen and Zenios (2006), the inability to raise adequate resources to finance profitable investment opportunities is called funding liquidity risk while trading liquidity risk exists when it becomes costly or impossible 
to sell off assets or enter into new positions to hedge current exposures as the need arises. Risk: The need to replace net outflows due to unanticipated withdrawal/non- renewal of deposits.

This problem gets accentuated in the context of change in the main liability structure of the banks, namely the maturity period for term deposits. For instance, in 1986, nearly 50\% of term deposits had a maturity period of more than 5 years and only 20\%, less than 2 years for all commercial banks. But in 1992, only $17 \%$ of term deposits were more than 5 years whereas 38\% were less than 2 years (Vaidyanathan, 1995).

\section{Credit Risk:-}

According to Valsamakis et al (2005), credit risk is the risk that a financial contract will not be concluded according to the agreement. It is the risk that the counterparty to an asset will default. In other words, it is the risk to earnings or capital due to borrowers' late and non- payment of loan obligations.

Credit risk encompasses both the loss of income resulting from the sector inability to collect anticipated interest earnings as well as the loss of principal resulting from loan defaults. Credit risk arises because the possibility that the expected cash flows from advances and securities held, might not be paid in full. Credit risk is considered the most lethal of the risks banks face (Cade, 1999) and can be grouped into transaction and portfolio risks.

1. Transaction risk refers to the risk within individual loans transaction risk is mitigated through borrower screening techniques, underwriting criteria and quality procedures for loan disbursement, monitoring, and collection.

2. Portfolio risk refers to the risk inherent in the composition of the overall loan portfolio. Policies on diversification (avoiding concentration in a particular sector or area), maximum loan size, types of loans, and loan structures lessen portfolio risk.

It is associated with the risk that foreign borrowers cannot repay the debt due to foreign currency shortages, adverse political and economic conditions or interference by the foreign government (Saunders \& Cornett, 2003).

\section{Currency Risk:-}

The risk that a bank may suffer losses as a result of adverse exchange rate movements during a period in which it has an open position, either spot or forward, or a combination of the two, in an individual foreign currency. Concerns the possible impact which fluctuations in exchange rates may have on the foreign exchange holdings or the commitments payable in foreign currencies by business organizations (Valsamakis, et al., 2005). It is the possibility that exchange rate fluctuations can adversely affect the value of a bank's assets and liabilities held in foreign currencies (Bessis, 2002). Currency risk is one of the market risks Banks face.

\section{Asset Liability Management Strategies and Techniques:-}

There are several risk management tools and techniques used in asset-liability models. Most of these tools are also used in portfolio allocation strategies. These can be grouped into two broad categories, namely; static models and stochastic models.

\section{Static Models:-}

This class of ALM models is suitable for modelling where expected changes in risk variables are small but well defined. Markowitz (1952) mean variance model is a classic example in this category. Where single period static models are used, typical asset liability management strategies would comprise Immunization, Dedication, Gap Management, Duration analysis, Value at Risk and Mean-Variance Analysis.

\section{Immunisation:-}

The concept of Immunisation was introduced by Redington (1952). He defined immunisation as the process of matching the distribution of the terms of assets and liabilities in order to reduce the possibility of loss due to changes in interest rates. De la Grandville (2007) on his part observed that the impact on an investor (a bondholder) of changes in interest rate largely depends on the investor's horizon. An investment horizon can be short or long and is calculated as the weighted average of a portfolio's times of payment where the weights depend on the present value of cash flows. He referred to this as duration and observed that the duration of a portfolio corresponds to the first moment and that it is possible to have higher order durations. However, De la Grandville (2007) finds that despite the importance of the concept of duration matching in portfolio risk management, it is not known how many 
moments should be used due to lack of an effective analytic model. He therefore tried to develop a general framework of immunisation that is also analytically tractable.

\section{Dedication:-}

Another important risk management strategy widely used in practice is Dedication. Romanyuk (2010) describes portfolio dedication as the process of obtaining full self- insurance against risk exposures by matching asset and liability cash flows. Where asset and liability cash flows cannot be fully matched, the difference between the cash flows is referred to as an asset-liability gap. The process of managing a negative gap where liability cash flows exceed cash flows of assets is called gap management. On the other hand, surplus management refers to the process of trying to reduce the cash flow mismatch where assets cash flows exceed that of liabilities. To allow greater flexibility and more realistic allocation of resources, these processes have sometimes been extended to take into account uncertainty and multi-period horizons. For example, Monfort (2008) investigates portfolio immunisation in the context of assets and liabilities where there are random events. Gajek (2005) studies immunisation strategies in the presence of stochastic interest rates while Zenios (1995) extends static immunisation and dedication strategies to accommodate stochastic processes using Monte Carlo simulations.

\section{Gap Analysis:-}

This measures the magnitude of any mismatch between assets and liabilities due to a maturity gap or a funding gap. This is used when assets and liabilities have different maturity profiles. The model examines the repricing gaps between assets and liabilities of different maturities. Repricing gap can be negative or positive. A negative repricing gap exists where liabilities are repriced earlier than assets. On the other hand, a positive repricing gap is where assets are repriced first. Repricing gaps measure the net interest income exposure to changes in interest rates in different maturity buckets (Consigli, 2007).

\section{Duration Analysis:-}

This model takes into account the different timings of the arrival of cash flows and the maturity of assets and liabilities and measures the sensitivity of interest rates on assets and liabilities. According to (Consigli 2007), this is calculated as the weighted average time to maturity of the present value of the cash flows. The greater the duration, the higher the sensitivity of the price of the asset or liability to changes in interest rates. The aim is to ensure complete immunisation by matching the duration of assets and liabilities. ALM would then aim at reducing the mismatch between durations.

This can be done in two ways: Asset driven or liability driven strategies. Whether asset or liability driven, the strategy adopted will depend on whether duration of assets is greater or lower than that of liabilities. Assuming that duration of assets is greater, an asset driven strategy would be to shorten the duration of assets in order to match duration of liabilities. This can be done through securitisation. Long-term asset portfolios such as finance leases and hire purchases are sold and the proceeds invested in short term assets or used to pay off short term debts. A typical liability driven ALM strategy on the other hand would focus on actions that increase the maturity profiles of liabilities. These would include financing assets with long-term debts, issuing more equity, convertible preference shares or convertible debentures. Other instruments that can be issued are redeemable debts, subordinated debt instruments as well as term loans. Where asset duration is lower than liability duration, bridging the gap would be necessary where interest rates are expected to rise. In that case, the strategy would be the exact opposite of asset and liability driven strategies discussed for the situation where asset duration exceeds that of liability.

\section{Value at Risk (VaR) Model:-}

This is used to measure the market risk of a portfolio of assets and liabilities with a particular focus on the tail risks due to Non-Gaussian distribution of asset returns. It is a measure of the maximum expected loss over a target horizon at a given confidence interval. It is a quantile-based measure of risk related to the percentiles of probability distributions usually, 95th or 99th percentile, which correspond to 95\% and 99\% VaR respectively (Martellini et al, 2003). The data used in VaR models come from many sources. They are based either on the historical market price and volatility observations or on Monte Carlo simulated market price distributions.

\section{Materials and methods:-}

According to Kotzar et al., (2005), research methodology is defined as the plan and structure of investigation and the way in which studies are put together and defines process of focusing on the researcher's perspective for the purpose of a particular study. This chapter outlines the research methodology of this study where the research was conducted 
in two phases in order to realize the stated objectives, the researcher utilized a combined approach that embraces features of both descriptive and exploratory designs. The methodology for this research is designed considering the main objectives of the study.

\section{Research Design:-}

Descriptive approach was adopted. It embraces features of both qualitative and quantitative type of research. This gives way for the qualitative and the quantitative research to be carried out since each would serve as a compensation for each other's weakness.

\section{Triangulation:-}

According to De Vos et al (2002), the concept of triangulation is sometimes used to designate a conscious combination of qualitative and quantitative methodology. Triangulation method refers to both mixing qualitative and quantitative approaches of research and data triangulation, and to the use of multiple data sources in a study was used in this study. It is believed that the use of triangulation of both method and data gave a more comprehensive picture of the factors contributing to non-performing assets amongst the selected Banks (Polit and Hungler, 1999).

\section{Methodology:-}

The research study area selected for the study is Lucknow which is the Administrative Headquarters of Uttar Pradesh. The study was conducted on a population that consisted of four (4) selected Banks in Lucknow. They are; SBI Bank, Axis Bank, HDFC Bank and Baroda Bank. Based on the number of branches of the above stated Banks, the total population for the research consisted of all the Banks in Lucknow. The sample size drawn was 60 out of the total population of asset liability staffs of the selected Banks. These sample respondents are involved in asset, liability and risk related activities in the selected Banks.

Multi-stage sampling was used to select respondents for the study. In the first stage, the total Banks were divided into branches located in cities, towns and villages. Among these, the convenient sampling technique was then adopted to select all Head Offices of each Bank located in the city for authentic response because ALM is done by senior Head Offices of Banks in India. Purposive sampling was further adopted to select two Public Banks and two Private Banks (SBI, Bank of Baroda, Axis Bank and HDFC Bank). Therefore, the sample frame was confined to those involved in asset, liability and risk management members of the selected Banks.

The survey was conducted using a structured questionnaire and structured record reviews of selected Banks. The questionnaire was divided into two parts. That is, open-ended questions as well as close-ended questions. In addition, there were questions on ranking factors according to the importance of the respondent's views and opinions. The study is based on both primary and secondary data sources. Primary data have been collected through administering of the administered questionnaires and discussions with managerial personnel, executives and staffs of the selected Banks. Secondary data such as RBI publications like, "Report on Trend and Progress of Banking in India", "Annual Report of RBI", and "Reports on Currency and Finance" are the major sources for this study. To supplement the data, the researcher elicited other relevant data available from the annual reports of the various public, private and foreign commercial Banks, journals, websites and text books. Finally, the data collected from the survey questionnaires were carefully coded and checked for consistency before inputting into the statistical software. The analysis was performed with SPSS version 16 and Excel 2016.

\section{Results and discussions:-}

This section is divided into two. They are; the results and discussions. Results of the data collected from the various respondents of the study are presented and discussed accordingly. The hypotheses developed for the study are also presented.

Reliability Statistics:-

Table 1:-Cronbach's Alpha Reliability Statistics.

\begin{tabular}{|c|c|c|}
\hline Cronbach's Alpha & Cronbach's Alpha Based on Standardized Items & N of Items \\
\hline .875 & .940 & 42 \\
\hline
\end{tabular}

Cronbach's alpha was calculated to measure the reliability of the questionnaire and the results obtained. The value of Cronbach's alpha is .961 which show very high level of consistency, thus showing the higher reliability of the 
instrument used in the study. This shows that the data was satisfactory because they met the minimum accepted level of 0.7 .

Research Hypothesis:-

H0: There is no relationship between risk factors and asset liability management of the various selected Banks for profitability.

H1: There is a relationship between the risk factors and the asset liability management of the selected Banks for profitability.

Table 2:-Regression Analysis.

Table 3:-ANOVA.

\begin{tabular}{|c|c|c|c|c|c|c|c|c|c|}
\hline \multicolumn{10}{|c|}{ Model Summary } \\
\hline \multirow[t]{2}{*}{ Model } & \multirow[t]{2}{*}{$\mathrm{R}$} & \multirow{2}{*}{$\begin{array}{c}\mathrm{R} \\
\text { Square }\end{array}$} & \multirow{2}{*}{$\begin{array}{c}\text { Adjusted } \\
\text { R } \\
\text { Square }\end{array}$} & \multirow{2}{*}{$\begin{array}{l}\text { Std. Error of } \\
\text { the Estimate }\end{array}$} & \multicolumn{5}{|c|}{ Change Statistics } \\
\hline & & & & & $\begin{array}{c}\text { R Square } \\
\text { Change }\end{array}$ & F Change & df1 & df2 & $\begin{array}{c}\text { Sig. F } \\
\text { Change }\end{array}$ \\
\hline 1 & $.895^{\mathrm{a}}$ & .801 & .706 & .61150 & .801 & 8.451 & 19 & 40 & .000 \\
\hline
\end{tabular}

The Regression coefficient ' $\mathrm{R}$ ' $=0.895$ or $89.8 \%$ which means that correlation between dependent variable and

\begin{tabular}{|c|c|c|c|c|c|c|}
\hline \multicolumn{7}{|c|}{ ANOVA $^{b}$} \\
\hline \multicolumn{2}{|c|}{ Model } & Sum of Squares & df & Mean Square & $\mathrm{F}$ & Sig. \\
\hline \multirow[t]{3}{*}{1} & Regression & 60.042 & 19 & 3.160 & 8.451 & $.000^{\mathrm{a}}$ \\
\hline & Residual & 14.958 & 40 & .374 & & \\
\hline & Total & 75.000 & 59 & & & \\
\hline \multicolumn{7}{|c|}{$\begin{array}{l}\text { a. Predictors: (Constant), Liquidity risk, Legal and regulatory, Operational risk, Counterparty risk, Credit risk, } \\
\text { Interest rate risk, foreign exchange risk. }\end{array}$} \\
\hline \multicolumn{7}{|c|}{$\begin{array}{l}\text { b. Dependent Variable: Risk is a major factor concerned for asset liability management for profitability in your } \\
\text { Bank. }\end{array}$} \\
\hline
\end{tabular}

independent variables is positive. The coefficient of determination ' $\mathrm{R} 2$ ' $=0.801$ indicating that $80.1 \%$ of variation in dependent variable is explained by independent variables. The F-test value of 8.451 is significant because the significance level is $=.000$ which is less than 0.05 .

Hence, null hypotheses will be rejected and alternative hypotheses will be accepted that retention is positively associated with Legal and regulatory risk, Credit risk, Foreign exchange risk, Interest rate risk, Counterparty, Operational risk is, Liquidity risk. This also implies that the correlation between dependent variable and independent variables is statistical significant and the regression model is valid.

Table 4:-Coefficients

\begin{tabular}{|c|c|c|c|c|c|c|}
\hline \multicolumn{7}{|c|}{ Coefficients } \\
\hline \multicolumn{2}{|c|}{ Model } & \multicolumn{2}{|c|}{ Unstandardized Coefficients } & \multirow{2}{*}{$\begin{array}{c}\text { Standardized } \\
\text { Coefficients } \\
\text { Beta }\end{array}$} & \multirow[t]{2}{*}{$\mathrm{t}$} & \multirow[t]{2}{*}{ Sig. } \\
\hline & & B & Std. Error & & & \\
\hline \multirow[t]{8}{*}{1} & (Constant) & 3.575 & 2.326 & & 1.537 & .132 \\
\hline & Liquidity & 4.074 & 1.190 & 0.938 & 3.422 & .001 \\
\hline & Legal and regulatory risk & -4.217 & 1.491 & -.941 & -2.827 & .007 \\
\hline & Operational risk & 2.347 & 1.296 & .865 & 1.811 & .078 \\
\hline & Counterparty risk & -2.561 & .645 & -0.144 & -3.968 & .000 \\
\hline & Credit risk & -1.735 & .479 & -.498 & -3.620 & .001 \\
\hline & Interest rate risk & 1.210 & .238 & 1.055 & 5.095 & .000 \\
\hline & Foreign exchange risk & .606 & .168 & .744 & 3.606 & .001 \\
\hline
\end{tabular}

a. Dependent Variable: Risk is a major concern for asset liability management for profitability in your Bank. 
- Liquidity risk $(\beta 1)=.94$ which implies that one percent increase in liquidity increase $94 \% \%$ of retention level if other variables are kept controlled. The T-test value 3.422 and significant at .001 which is less than the 0.05 . The relationship is positive and statistically significant and the regression model is valid.

- Legal and regulatory risk $(\beta 2)=.94$ or $94 \%$ which implies that one percent increase in Legal and regulatory risk increase by $94 \%$ of retention level if other variables are kept controlled. The T-test value is -2.827 and significant at .007 level which is less than the 0.05 . The relationship is significant and the regression model is valid.

- Operational risk $(\beta 3)=0.865$ or $86.5 \%$ which implies that one percent increase in qualification of employees increase $86.5 \%$ of retention level if other variables are kept controlled. The T-test value is 1.188 and significant at .078 level which is more than the 0.05 . The relationship is insignificant dues to the fact that, operational risk is not a factor in ALM management.

- Counterparty risk $(\beta 4)=0.144$ with T-test value is 4.399 and significant at .000 level which is less than the 0.05 . The relationship is significant and the regression model is valid.

- Credit risk $(\beta 5)=.498$ or $49.8 \%$ which implies that one percent increase in credit risk increases $49.8 \%$ of retention level if other variables are kept controlled. The T-test value is -3.620 and significant at .001 level which is less than the 0.05 . The relationship is significant and the regression model is valid.

- Interest rate risk $(\beta 6)=.055$ or $5.5 \%$ which implies that one percent increase in interest rate risk increases $5.5 \%$ of retention level if other variables are kept controlled. The T-test value is 5.095 and significant at .000 level which is less than the 0.05 . The relationship is significant and the regression model is valid.

- Foreign exchange risk $(\beta 7)=0.71$ or $71 \%$ which implies that one percent increase in foreign exchange risk increases $71 \%$ of retention level if other variables are kept controlled. The T-test value is 3.608 and significant at .001 level which is less than the 0.05 . The relationship is significant and the regression model is valid.

Table 5:-Chi-Square Tests.

\begin{tabular}{|l|l|c|c|c|c|}
\hline & \multicolumn{1}{|c|}{ Items } & $\begin{array}{c}\text { Chi square } \\
\text { value }\end{array}$ & df & Asymp. Sig & Results \\
\hline & & & & & .000 \\
\hline & ALM Principles and objectives & 48.600 & 1 & .000 & Supported \\
\hline & ALCO for ALM & 48.600 & 1 & .000 & Supported \\
\hline & ALCO meetings frequency & 57.500 & 4 & .000 & Supported \\
\hline & Chief risk officer & 41.667 & 1 & .000 & Supported \\
\hline & Interest rate strategy for mismatch & 24.067 & 1 & .020 & Supported \\
\hline & External strategist & 5.400 & 1 & .439 & Not Supported \\
\hline & Strategy effectiveness & .600 & 1 & .002 & Supported \\
\hline & Interest rate derivatives & 16.667 & 4 & .000 & Supported \\
\hline & Derivatives effectiveness & 29.400 & 1 & .000 & Supported \\
\hline
\end{tabular}

The table above shows the relation between the banks strategies the various strategies for managing interest rate risk to ensure profitability of banks. The survey research was conducted on 60 respondents from the four selected banks proposed for the study.

Q31. ALM principles and objectives: As per the table, it can be inferred that, the test was valid with Asymp significance of .000 which is less than $.05 . \mathrm{p}<.05$. Per this, we can conclude that, the result is significant and supported.

Q32. ALCO team for ALM: From the table, the results can be inferred that, the test was valid with Asymp significance of .000 which is less than $.05 . \mathrm{p}<.05$. Per this, we can conclude that, the result is significant and supported.

Q33. ALCO meetings frequency: The results from the table shows a Chi square values of 57.500, with Asymp significance of .000 which is less than .05 . ( $\mathrm{p}<.05)$. Therefore, we can conclude that, the result is significant and supported.

Q34. Chief credit officer: As per the table, it can be inferred that, the test was valid with asymp significance of .000 which is less than .05. $\mathrm{p}<.05$. Per this, we can conclude that, the result is significant and supported. 
Q35. Interest strategy for managing mismatch: There is a significant level of .000 with a Chi square value of 24.07 which shows that the test was valid since is. $\mathrm{p}<.05$. Per this, we can conclude that, the result is significant and supported.

Q36. External strategist for ALM: As per the table, it can be inferred that, the test was valid with Asymp significance of.020 i.e $\mathrm{p}<.05$. And we can conclude that, the result is significant and supported.

Q37. Effectiveness of strategy: The results from the table shows a Chi square values of .600, with Asymp significance of .439 which is more the level of tolerance $(\mathrm{p}>.05)$. Therefore, we can conclude that, the result is insignificant and unsupported.

Q38. Use of derivatives for interest rate: The results from the table shows a Chi square values of 16.667 , pf of 4 and Asymp significance of .002 which is less than level of tolerance $(\mathrm{p}<.05)$. Therefore, we can conclude that, the result is significant and supported.

Q39. Derivatives effectiveness: The results from the table shows a Chi square values of 29.400, pf of 1 and Asymp significance of .000 which is more the level of tolerance $(\mathrm{p}>.05)$. Therefore, we can conclude that, the result is insignificant and unsupported

Q 40. Overall ratings: From the table, the results can be inferred that, the 60 respondents who were selected for the research attested to the fact the, there is a formal stated principles and strategies which are used to hedge against interest rate risk, mismatch and its volatility. The test was valid with Asymp significance of .000 which is less than .05 . $\mathrm{p}<.05$. Per this, we can conclude that, the result is significant and supported.

\section{Conclusion and recommendations:-}

This survey assessed the risk factors associated with Asset Liability Management and the various strategies for managing the interest rate risks of assets and liabilities with the focus on four Banks and sixty respondents drawn from the population. These included all the banks employees who were related to asset and liabilities management. The study portrayed that there are laid down strategies and policies used for credit management assessment in the bank which are formulated by the top management in conjunction with the directors of the company. Below is the summary of the resulting findings;

- Firstly, it became evident that the selected banks have principles, guidelines and policies that serve as a guideline for effective asset liability management. The banks' asset and liabilities; require that its system and procedure for assessing the mismatches associated with it so as to be very effective, secured and manageable. This should basically be in terms of the complying with RBI guidelines, following banks principles and adhering to all asset liability factors in its management.

- Notwithstanding of the said findings, the research revealed that, the banks have greater scope to manage interest rate risk through various techniques. All the selected banks have strategies that are being mounted against interest rate since it is the major concern that affect banks asset and liabilities.

- It was understood through the study, that interest rate risk is measured through the use of re-pricing gap analysis and duration analysis. Therefore, it was found that both private and public Banks selected for the study had strategic pillars that are used for interest rate risk management. It was evident that; all the banks also contract external strategist o help in combating interest rate risk.

- It was also revealed that all the selected Banks agreed that risk is a major factor that raises concerns for effective asset liability management for profitability. Interest rate risk, liquidity risk, credit risk and foreign exchange risk are considered as part of asset liability management. Emphasis was made by the Banks that, interest rate and foreign exchange risk are ranked as the major risk factors affecting the assets and liabilities of the selected banks.

- Last but one, the research discovered that, all the four selected banks that were selected for the study has Asset Liability Committee (ALCO) which is headed by a Chief ALCO Officer who coordinates all the various activities related to the management of assets and liabilities. This shows that banks in India are much concerned about the efficacy of asset liability leading to growth and profitability in banks.

- Finally, the banks use derivatives strategies for management of interest rate risks of the Banks. One major strategy used to hedge against interest rate risk was derivative strategy which was rated as an effective tool for managing the mismatch and maturity risk in interest rate risk. 


\section{Recommendations:-}

- There should be effective awareness for ALM in the Bank staff at all levels-supportive Management and dedicated Teams.

- Furthermore, it is recommended that Asset Liability Management is one of the vital tools for risk management in Banks and Banks have to take great care for that. All banks have to work properly with regard to the ALM so as to increase their performance.

- Maintaining a good interest risk management is vital for Indian banks in the present scenario. It enables the Banks to reduce earnings volatility and gives opportunity to benefit from changing interest rates. The rule based system will ease the work of ALM analyst and assist him/her in effective decision making.

\section{References:-}

1. Bessis J. (2002): Risk Management in Banking. 2nd edition. London: John Wiley \& Sons Ltd.

2. Cade, E. (1999): Managing Banking Risks. Chicago: Glenlake Publishing Company, Ltd.

3. Consigli, G. (2007): Asset-Liability Management for Individual Investors. In Handbook of Asset and Liability Management, Volume 2: Applications and Case Studies, Chapter 17, edited by Zenios, S. A. and Ziemba, W. T. Amsterdam: Elsevier.

4. Consigli, G. and Dempster, M. A. H. (1998): Dynamic Stochastic Programming for AssetLiability Management. Annals of Operations Research, 81(1), 131-61.

5. De la Grandville, O. (2007): Protecting Investors against Changes in Interest Rates. In Hand-book of Asset and Liability Management, Volume 1: Theory and Methodology, Chapter 3, edited by Zenios, S. A. and Ziemba, W. T. Amsterdam: Elsevier.

6. Gajek, L. (2005): Axiom of Solvency and Portfolio Immunization under Random Interest Rates. Insurance, Mathematics and Economics, 36: 317-328. Gup, B.E. and Brooks, R. (1993), Interest Rate Risk Management, Irwin Professional Publishing, Burr Ridge.

7. De Vos,Strydom,Fouche\&Delport. (2002): Researches Grass Roots for Social Sciences Human Service Professions. 2nd ed. Pretoria: Van Schaik Publishers.

8. Kotzar, H., Seuring, S., Muller, M. \& Reiner, G. 2005: Research methodologies in supply chain management, Yhysica-Verlag, Germany: Heidelberg.

9. Madura J. (2005): Financial Markets, Institutions and Instruments,South-Western College Publishing, USA.

10. Markowitz, H. M. \& van Dijk, E. (2006): Risk-Return Analysis. In Handbook of Asset and Liability Management, Volume 1: Theory and Methodology, Chapter 4, edited by Zenios, S. A. and Ziemba, W. T. Amsterdam: Elsevier.

11. Martellini, L., Priaulet, P. and Priaulet, S. (2003): Fixed-Income Securities: Valuation, Risk Management and Portfolio Strategies. Wiley Finance Series. John Wiley \& Sons Ltd. ISBN 0-470-85277.

12. Monfort, A. (2008): Optimal Portfolio Allocation under Asset and Surplus VaR Constraints. Journal of Asset Management, 9(3): 178-192.

13. Redington, F. M. (2007): Review of the Principles of Life-Office Valuations. Journal of the Institute of Actuaries, 78: 286-340.

14. Romanyuk, Y. (2010): Asset-liability management: An overview (No. 2010-10). Bank of Canada Discussion Paper.

15. Rosen and Zenious. (2006): Bank Loan Loss Provision: A Reexamination of Capital Management and Signaling Effects, Working Paper, Department of Accounting, Syracuse University, 1-37.

16. Saunders A\& Cornett MM. (2003): Financial Institution Management, 4th edition. New York: McGrawHill/Irwin.

17. Valsamakis, A.C., Vivian, R.W. \& Du Toit, G.S. (2005): Risk Management: managing enterprise risks. $3^{\text {rd }}$ edition. South Africa: Heinemann Publishers

18. Vaidyanathan, R. (1999): Asset Liability Management: Issues and trends in Indian context," ASCI Journal of Management, 29 (1)

19. Vaidyanathan, R. (1995): Debt market in India: Constraints and prospects. Bangalore: Centre for Capital Markets Education and Research, Indian Institute of Management-Bangalore. 